\title{
Thermodynamic Properties of Water Adsorption on Gaplek Flour Fortified with Red Bead Tree Seed
}

\author{
Margareta Novian Cahyanti ${ }^{1 *}$, Alvama Pattiserlihun ${ }^{2}$ \\ ${ }^{1}$ Chemisty Program, Science and Mathemathics Faculty, Satya Wacana Christian University, \\ Salatiga, Indonesia \\ ${ }^{2}$ Physics Education Program, Science and Mathemathics Faculty, Satya Wacana Christian University, \\ Salatiga, Indonesia \\ *email : margareta.cahyanti@staff.uksw.edu
}

Received December 18, 2017; Accepted August 27, 2018; Available online December 8, 2018

\begin{abstract}
The moisture sorption isotherm data of gaplek flour fortified with red bead tree seed stored in a chamber, the relative humidity of chamber ranging from $10 \%$ to $97 \%$ regulated using a saturated salt solution, was determined at three temperatures $25^{\circ}, 35^{\circ}$, and $45{ }^{\circ} \mathrm{C}$. The experimental data used to determine the thermodynamic functions were isosteric heat of sorption, sorption entropy, and free energy changes. The sorption isosteric heats were determined by the application of the Clausius-Clapeyron equation. Isosteric heats of adsorption increased to maximum level and then declined with increase of moisture content. Adsorption entropy increased to maximum level and then declined with the increase of moisture content. The free energy changes increased with increase in moisture content. The spreading pressure increased with increasing water activity.
\end{abstract}

Keywords: Gaplek, Red Bead Tree Seed, Thermodynamic, Isotherm

\section{INTRODUCTION}

Gaplek flour fortified with red bead tree seed is flour made from cassava by a fermentation process by tempeh yeast and fortified with red bead tree seed. In the process of making flour, cassava underwent a drying process. Dehydrated food products are susceptible to damage due to the rising of moisture content. The moisture content in the food product will form the equilibrium with relative humidity. The relationship between water activity and moisture content of food product is explained by means of moisture sorption isotherm. To describe this curve, there have been several models developed such as Guggenheim Anderson de Boer (GAB), Brunauer-EmmettTeller (BET) dan Caurie. In our previous paper (Cahyanti and Pattiserlihun, 2017) the Guggenheim Anderson de Boer (GAB) model and equation were found to be the best model and equation in describing the sorption isotherm of gaplek flour fortified with red bead tree seed. GAB model is the best fit not only for gaplek flour fortified with red bead tree seed but also for another flour such as fermented cassava flour by red yeast rice (Alfiah, Hartini, \& Cahyanti, 2017), fermented sweet potato flour by red yeast rice (Rukmawati, Hartini, \& Cahyanti, 2017), and gluten-free flour (Jha, Dahiya, \& Singh, 2014).
Further analysis of sorption isotherm data by application of thermodynamic principles can provide much important information. First, the thermodynamic properties of food connect the concentration of water in food with its partial pressure, which is crucial for the analysis of mass and heattransport phenomena during dehydration. Second, the thermodynamic properties determine the endpoint to which foods must be dehydrated in order to achieve a stable product with optimal moisture content. Third, the enthalpy of sorption yields a figure for the theoretical minimum amount of energy required to remove a given amount of water from food. Finally, the understanding of thermodynamic properties can provide an insight into the microstructure associated with a food, as well as theoretical interpretations for the physical phenomena occurring at foodwater interfaces (Rizvi, 2014).

When water is removed from a food by a drying process, heat is absorbed. Heat is required because water moves against a gradient of water activity or against an increase in osmotic pressure. The isosteric heat of sorption is an indicator of the state of water hold by the solid material. Net isosteric heat of sorption is the difference of total heat of sorption in the food and the heat of vaporation of water associated with the sorption process 
(Basu, Shivhare, \& Mujumdar, 2006). By knowing the net isosteric heat of sorption, the actual energy required for drying a product to a specific moisture content can be calculated (Sormoli \& Langrish, 2014)The differential entropy value is proportional to the number of active adsorption sides at the specified energy level (Tog rul \& Arslan, 2006). This means that the amount of available sorption sites decreases with increased moisture as the active site is covered by water molecules, thereby reducing their mobility (Aponte, 2016).

In this paper, the fitted equation was used to determine thermodynamic properties related to the moisture sorption on gaplek flour fortified with red bead tree seed such as net isosteric heat, isosteric heat of sorption, differential entropy of sorption, free energy changes, and spreading pressure.

\section{EXPERIMENTAL SECTION}

The materials used were cassava and red bead tree originally from Salatiga, fermentation yeast, aqua dest, $\mathrm{NaOH}, \mathrm{MgCl}_{2}, \mathrm{~K}_{2} \mathrm{CO}_{3}$, $\mathrm{Mg}\left(\mathrm{NO}_{3}\right)_{2}, \mathrm{KI}, \mathrm{NaCl}$, and $\mathrm{KCl}$. The tools used were drying cabinet, grinder, 61 mesh strainer, incubator, sorption container, and moisture analyzer Ohaus BM 25.

The flour was made based on the previous research (Maidawati, 2011). The cassava was peeled and then washed. Next, cassava was cut into small pieces and dumped for one night in a $10 \%$ salt solution. The next day, cassava was dried using the drying cabinet at a temperature of $50{ }^{\circ} \mathrm{C}$ for two days. The red bead tree was washed and damped for a night. Then, it was boiled until the skin opened (more or less 2 hours). The crust and cuticle were thrown. Next, it was dried at a drying cabinet for two days at a temperature of $50{ }^{\circ} \mathrm{C}$. After it is dried entirely, it was ground using a grinder.

"Gaplek" was steamed for 30 minutes and then cooled. After cooled down, "gaplek" was added by $13.16 \%(\mathrm{~b} / \mathrm{b})$ red bead tree flour as the source of protein. It was then inoculated using fermentation yeast as much as $5 \%(\mathrm{~b} / \mathrm{b})$ and fermented for 40.12 hours. Fortified "gaplek" was dried in a drying cabinet for two days at a temperature of $50{ }^{\circ} \mathrm{C}$. It was then ground and strained using 61 mesh strainers. The initial moisture content of the product was determined using the Ohaus BM 25 moisture analyser.
The measurement of equilibrium moisture content was conducted based on the previous research (Budijanto, Sitanggang, \& Kartika, 2010) which had been modifying the type of salt and the storage temperature. This research used 7 kinds of saturated salt solution such as $\mathrm{NaOH}, \mathrm{MgCl}_{2}, \mathrm{~K}_{2} \mathrm{CO}_{3}, \mathrm{Mg}\left(\mathrm{NO}_{3}\right)_{2}$, $\mathrm{KI}$, $\mathrm{KCl}$, and $\mathrm{NaCl}$. It was done to form certain $\mathrm{RH}$ and storage temperature of $298 \mathrm{~K}, 308 \mathrm{~K}$, and $318 \mathrm{~K}$. The study was conducted in three repetitions. Equilibrium moisture content and water activity data are then modelled using the $\mathrm{GAB}$ equation. The GAB equation can be written as Eq (1)

$$
m=\frac{m_{o} C_{G A B} k_{G A B} a_{w}}{\left(1-k_{G A B} a_{w}\right)\left(1-k_{G A B} a_{w}+k_{G A B} a_{w} C_{G A B}\right)}
$$

where $\mathrm{m}$ is equilibrium moisture content (\% dry basis), $\mathrm{m}_{\mathrm{o}}$ is monolayer moisture content (\% dry basis), $\mathrm{a}_{\mathrm{w}}$ is water activity, $\mathrm{C}_{\mathrm{GAB}}$ is constant related to absorption heat in monolayer area, $\mathrm{k}_{\mathrm{GAB}}$ is constant related to absorption heat in the multilayer area. Eq (1) can be converted to a second order equation commonly written in Eq (2).

$$
\frac{a_{w}}{m}=A a_{w}^{2}+B a_{w}+C
$$

Where $\mathrm{A}, \mathrm{B}$, and $\mathrm{C}$ are the coefficients dependent of temperature. By combining Eq. (2) and GAB equation, other expressions to estimate $\mathrm{m}_{\mathrm{o}}, \mathrm{C}_{\mathrm{GAB}}$ and $\mathrm{k}_{\mathrm{GAB}}$ may be considered in $\mathrm{Eq}$ (3), (4) and (5).

$$
\begin{aligned}
& m_{o}=\frac{1}{\left(B^{2}-4 A C\right)^{\frac{1}{2}}} \\
& C_{G A B}=\frac{2}{1-\left(\frac{B^{2}}{B^{2}-4 A C}\right)^{\frac{1}{2}}} \\
& k_{G A B}=\frac{\left(B^{2}-4 A C\right)^{\frac{1}{2}}-B}{2 C}
\end{aligned}
$$

The resulting 2 nd order equation is then used for the determination of water activity at a predetermined moisture content for the determination of thermodynamic properties.

The moisture absorption data of the equation is best for the three temperatures used to calculate net isosteric heat by ClausiusClapeyron linear method (Rizvi, 2014).

$$
\ln \frac{a_{w 2}}{a_{w 1}}=\frac{q_{s t}}{R}\left(\frac{1}{T_{1}}-\frac{1}{T_{2}}\right)
$$

where $\mathrm{q}_{\mathrm{st}}$ is the net isosteric heat of sorption $(\mathrm{kJ} / \mathrm{mol})$ the amount of energy by which the heat of vaporization of moisture in a product exceeds the latent heat of pure water, $a_{w}$ the water activity, $\mathrm{R}$ the gas constant (8.314 
$\mathrm{J} / \mathrm{molK}$ ) and $\mathrm{T}$ the absolute temperature $(\mathrm{K})$. The isosteric heat of sorption $\left(\mathrm{Q}_{\mathrm{st}}\right)$ was calculated from the relationship (Togrul \& Arslan, 2007):

$$
Q_{s t}=q_{s t}+q_{c}
$$

where $q_{c}$ is the latent heat of vaporization of pure water $(43.53 \mathrm{~kJ} / \mathrm{mol})$ at $35{ }^{\circ} \mathrm{C}$, the average temperature used in this study.

The differential entropy $\left(S_{d}\right)$ (sorption entropy) of a material is proportional to the number of available sorption sites at a specific energy level. The $S_{d}$ of adsorption of water at each moisture content was obtained using Eq. (8) (Solomon \& Zewdu, 2016).

$$
-\ln a_{w}=\frac{Q_{s t}}{R T}-\frac{S_{d}}{R}
$$

After plotting $\ln \mathrm{a}_{\mathrm{w}}$ versus $1 / \mathrm{T}$ for given moisture content, $S_{d}$ was determined from the intercept $\left(\mathrm{S}_{\mathrm{d}} / \mathrm{R}\right)$.

The free energy changes $(\Delta \mathrm{G})$ was calculated using Eq. (4) (Rizvi, 2014; Goula, Karapantsios, Achlilias, \& Adamopoulos, 2008; Telis, Gabas, Meneggalli, \& TelisRomero, 2000; Aponte, 2016).

$$
\Delta G=R T \ln \left(a_{w}\right)
$$

where $\Delta G$ is the free energy changes $(\mathrm{J} / \mathrm{mol})$, $\mathrm{a}_{\mathrm{w}}$ the water activity, $\mathrm{R}$ the gas constant (8.314 $\mathrm{J} / \mathrm{molK})$, and $\mathrm{T}$ the absolute temperature $(\mathrm{K})$. Another researchers stated that the change in free energy for the adsorption process would be negative. free energy change is positive for the desorption process (Meze'e, Ngamveng, \& Bardet, 2008; de Oliveira, Correa, de Oliveira, Reis, \& Devilla, 2015). The effect of a change in water sorption on free energy is usually accompanied by changes on both enthalpy and entropy (Telis, Gabas, Meneggalli, \& TelisRomero, 2000).

Spreading pressure is another name of surface potential. It is the force applied in the surface plane perpendicular to each unit length of the edge to keep the surface from spreading. It also called the surface excess free energy. It was calculated using an analytical procedure using Eq (10).

$$
\varnothing=\frac{k T}{A_{m}} \int_{0}^{a_{w}} \frac{m}{a_{w} m_{o}} d a_{w}
$$

where $\mathrm{k}$ is Boltzman constant $\left(1.38 \times 10^{-23} \mathrm{~J} / \mathrm{K}\right)$, $A_{m}$ is the area that occupies one single water molecule at monolayer $\left(1.06 \times 10^{-19} \mathrm{~m}^{2}\right)$.

Combine Eq (1) and Eq (10) mathematically expressed the spreading pressure in the form of $\mathrm{GAB}$ equation in Eq (11) (Naveen \& Das, 2015; Monteagudo \& Fierro, 2012)

$$
\emptyset=\frac{k T}{A_{m}} \ln \left[\frac{1-k_{G A B} a_{w}+k_{G A B} a_{w} C_{G A B}}{1-k_{G A B} a_{w}}\right]
$$

Spreading pressure can then be used for the determination of net integral thermodynamic properties. Net thermodynamic integrals are thermodynamic properties at a same spreading pressure.

\section{RESULTS AND DISCUSSION}

The moisture content when it was an equilibrium between samples and surrounding is called equilibrium moisture content. The equilibrium moisture content of "gaplek" flour fortified with protein from red bead tree flour is shown at Table 1. Equilibrium moisture content and water activity data were then modelled using the GAB equation. The equation of the second-order line generated by the $\mathrm{GAB}$ equation for each temperature was displayed in Table 2.

Table 1. Relative Humidity $(\mathrm{RH})$, Water activity $\left(\mathrm{a}_{\mathrm{w}}\right)$ and Equilibrium moisture content $(\mathrm{m})$ at the temperature of $298 \mathrm{~K}, 308 \mathrm{~K}$, and $318 \mathrm{~K}^{*}$ )

\begin{tabular}{cccccccccc}
\hline Temperature & \multicolumn{3}{c}{$298 \mathrm{~K}$} & \multicolumn{3}{c}{$308 \mathrm{~K}$} & \multicolumn{3}{c}{$318 \mathrm{~K}$} \\
\hline Salt & $\begin{array}{c}\mathrm{RH} \\
(\%)\end{array}$ & $\mathrm{a}_{\mathrm{w}}$ & $\begin{array}{c}\mathrm{m} \\
(\% \mathrm{db})\end{array}$ & $\begin{array}{c}\mathrm{RH} \\
(\%)\end{array}$ & $\mathrm{a}_{\mathrm{w}}$ & $\begin{array}{c}\mathrm{m} \\
(\% \mathrm{db})\end{array}$ & $\begin{array}{c}\mathrm{RH} \\
(\%)\end{array}$ & $\mathrm{a}_{\mathrm{w}}$ & $\begin{array}{c}\mathrm{m} \\
(\% \mathrm{db})\end{array}$ \\
\hline $\mathrm{NaOH}$ & 11.33 & 0.11 & $6.05 \pm 0.50$ & 10.00 & 0.10 & $4.91 \pm 0.35$ & 10.00 & 0.10 & $4.55 \pm 0.15$ \\
$\mathrm{MgCl}_{2}$ & 36.00 & 0.36 & $8.69 \pm 0.77$ & 33.33 & 0.33 & $8.25 \pm 0.31$ & 30.33 & 0.30 & $7.58 \pm 0.47$ \\
$\mathrm{~K}_{2} \mathrm{CO}_{3}$ & 46.00 & 0.46 & $10.64 \pm 0.33$ & 44.00 & 0.44 & $9.70 \pm 0.28$ & 43.33 & 0.43 & $8.76 \pm 0.17$ \\
$\left.\mathrm{Mg} \mathrm{NO}_{3}\right)_{2}$ & 54.33 & 0.54 & $11.91 \pm 0.36$ & 53.33 & 0.53 & $10.83 \pm 0.30$ & 49.33 & 0.49 & $8.89 \pm 0.78$ \\
$\mathrm{KI}$ & 77.00 & 0.77 & $14.86 \pm 0.25$ & 73.00 & 0.73 & $13.36 \pm 0.40$ & 74.67 & 0.75 & $12.13 \pm 0.24$ \\
$\mathrm{NaCl}$ & 83.33 & 0.83 & $16.66 \pm 0.15$ & 82.67 & 0.83 & $15.38 \pm 0.38$ & 86.33 & 0.86 & $15.17 \pm 0.44$ \\
$\mathrm{KCl}$ & 93.33 & 0.93 & $20.01 \pm 0.79$ & 92.67 & 0.93 & $16.57 \pm 1.71$ & 96.33 & 0.96 & $18.50 \pm 0.20$ \\
\hline
\end{tabular}

*): averaged result of 3 times repetitions, some data already published in the previous publication

(Cahyanti \& Pattiserlihun, 2017) 
Table 2. The Equation of The Second-Order Line Generated by The GAB Equation for Each Temperature

\begin{tabular}{cc}
\hline Temperature & \multicolumn{1}{c}{ Equation } \\
\hline $298 \mathrm{~K}$ & $\frac{\mathrm{a}_{\mathrm{w}}}{\mathrm{m}}=-0.0813 \mathrm{a}_{\mathrm{w}}^{2}+0.1194 \mathrm{a}_{\mathrm{w}}+0.0066$ \\
$308 \mathrm{~K}$ & $\frac{\mathrm{a}_{\mathrm{w}}}{\mathrm{m}}=-0.0638 \mathrm{a}_{\mathrm{w}}^{2}+0.1065 \mathrm{a}_{\mathrm{w}}+0.0109$ \\
$318 \mathrm{~K}$ & $\frac{\mathrm{a}_{\mathrm{w}}}{\mathrm{m}}=-0.1011 \mathrm{a}_{\mathrm{w}}^{2}+0.1451 \mathrm{a}_{\mathrm{w}}+0.0072$ \\
\hline
\end{tabular}

Whereas the monolayer moisture content, $\mathrm{C}_{\mathrm{GAB}}$, and $\mathrm{k}_{\mathrm{GAB}}$ for each temperature shown in Table 3.

Table 3. Monolayer moisture content $\left(\mathrm{m}_{\mathrm{o}}\right)$, $\mathrm{C}_{\mathrm{GAB}}$, and $\mathrm{k}_{\mathrm{GAB}}$ for Each Temperature

\begin{tabular}{cccc}
\hline Temperature & $\mathrm{m}_{\mathrm{o}}$ & $\mathrm{C}_{\mathrm{GAB}}$ & $\mathrm{k}_{\mathrm{GAB}}$ \\
\hline $298 \mathrm{~K}$ & 7.80 & 29.5339 & 0.6570 \\
$308 \mathrm{~K}$ & 8.41 & 19.2551 & 0.5663 \\
$318 \mathrm{~K}$ & 6.46 & 31.8912 & 0.6742 \\
\hline
\end{tabular}

The isosteric heat of sorption $\left(\mathrm{Q}_{\mathrm{st}}\right)$ that indicates the binding energy or intermolecular force between water vapor molecules in the product's surface was calculated using Eq. (6) and Eq. (7) in the range of equilibrium moisture content of $2-18 \%$ dry basis. The relationship between isosteric heat of sorption and given moisture content was represented in Figure 1. Isosteric heats of adsorption increase to maximum level and then decrease with increase in moisture content. The increase of isosteric heats of adsorption occurs in the range of water content of 2-6\% dry basis and were between $49.96-60.93 \mathrm{~kJ} / \mathrm{mol}$. At moisture levels above $6 \%$ dry basis, isosteric heat has decreased. In this study on the water content of $18 \%$ dry basis isosteric heat amounted to $47.10 \mathrm{~kJ} / \mathrm{mol}$.

The similar result report by an earlier researcher. Previous research on the thermodynamic properties of water absorption by cassava flour is done by Aponte (2016). Isosteric heat measurements were carried out in the moisture content range of 0.058 to 0.30 $\mathrm{g}$ water/g matter dry basis. Isosteric heat ranges from 47.10 to $88.49 \mathrm{~kJ} / \mathrm{mol}$. The result shows a decrease in the isosteric heat along with rising moisture content. Research about thermodynamics properties of moisture sorption in whole black peppercorns found the same trend (Yogendrarajah, Samapundo, Devlieghere, De Saeger, \& De Meulenaer, 2015). Another research by Togrul \& Arslan (2007) found that isosteric heats of adsorption of walnut kernels increase to maximum level and then decrease with increase in moisture content.

At low moisture content, moisture is easily absorbed on the exterior surface of the solid. As the water content increases, the material swells and new high energy sites are opened up for water to get bound to. This results in increased heat at low moisture levels until the strongest binding site is covered.

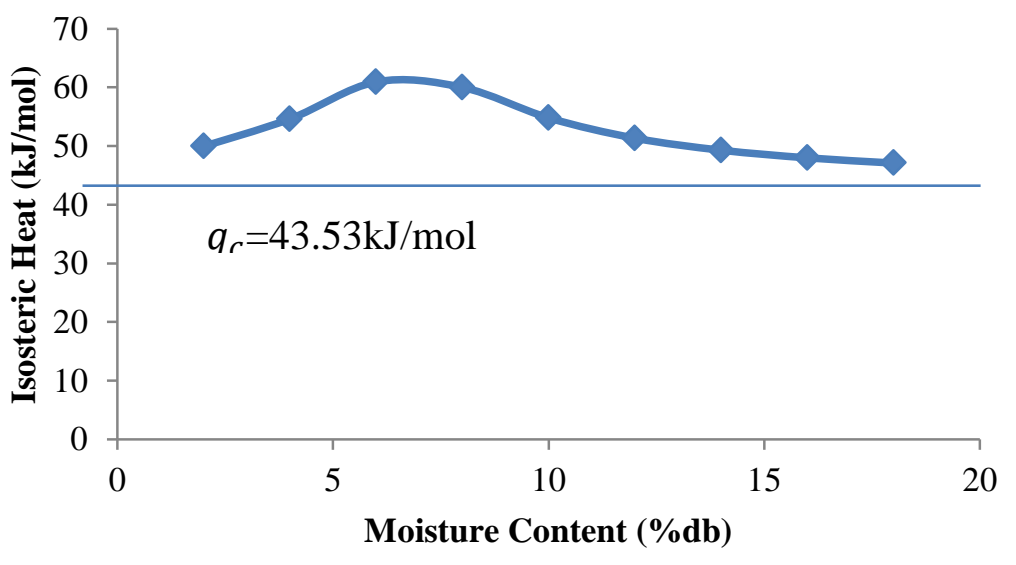

Figure 1. Variation of Isosteric Heat of Adsorption with Moisture Content 
The net integral enthalpy then reaches a maximum value and declines as less favorable locations are covered and as multiple layers of sorbed water form.(Aviara \& Ajibola, 2002). Togrul and Arslan (2007) state that the maximum enthalpy value indicates the bonding site with the highest binding energy begins to be covered by water. After all the sites are covered with water the multilayer with lower binding energy begins to form.

There is a relationship between moisture content and transport properties. In Region I (0-5\% moisture), the pores and capillaries are filled with air, which gradually fills with absorbed water vapor. Heat is released by water adsorption in solids and increases in thermal diffusivity (Kostaropoulus \& Saravacos, 1997). The increasing of thermal diffusivity causes specific heat decrease. This may be explained because of the specific heat is thermal conductivity divided by the product of the bulk density and thermal diffusivity. Specific heat is inversely proportional to the thermal conductivity (Irtwange \& Igbeka, 2003). At the same time, the diffusivity of moisture increases, because the water monomolecular layer is formed rapidly on the solid surface. The interaction between water and food surface is very strong, isosteric heat rises to its maximum value (Kostaropoulus \& Saravacos, 1997).

In region II (humidity 5-30\%), moisture absorbed in multimolecular layers and capillaries filled gradually with water. This causes the thermal diffusivity and moisture diffusivity to decrease (Kostaropoulus \& Saravacos, 1997). The decreasing of thermal diffusivity causes specific heat increase. The interaction between water and food surface is very strong, isosteric heat rises to its maximum value. The multilayer layer of adsorbed water is formed from the polar end of the monolayer layer with the new water molecule. This layer has a lower interaction with the surface of flour.

The differential entropy of adsorption was calculated using Eq. (8) in the range of equilibrium moisture content of $4-18 \%$ dry basis. The differential entropy of adsorption as a function of equilibrium moisture content was represented in Figure 2. The differential entropy of adsorption has a small value at low moisture content and then tends to rise to a certain point along with the increase in moisture content. If the differential entropy of absorption reaches the maximum value then the entropy falls along with the increase in water content.

The increase of differential entropy of adsorption occurs in the range of water content of $4-8 \%$ dry basis and were between $12.85-$ $43.64 \mathrm{~J} / \mathrm{molK}$. At moisture levels above $8 \%$ dry basis, differential entropy of adsorption has decreased. In this study on the water content of $18 \%$ dry basis differential entropy of adsorption amounted to $11.06 \mathrm{~J} / \mathrm{molK}$. The same trend found by earlier research. Previous research on the thermodynamic properties of water absorption by cassava flour is done by Aponte (2016). Differential entropy of adsorption measurements is carried out in the moisture content range of 0.058 to $0.30 \mathrm{~g}$ water/g matter dry basis. The result shows a decrease in the differential entropy of adsorption along with rising moisture content. The maximum differential entropy of adsorption at $0.058 \mathrm{~g}$ water /g matter dry basis amounted to $129 \mathrm{~J} / \mathrm{molK}$. Another research about differential entropy of adsorption in sorghum also found the same trend (Bonner \& Kenney, 2013). Differential entropy of adsorption measurements was carried out in the moisture content range of 5 to $40 \%$ dry basis. The result displaying an initial rise as moisture increases, followed by an exponential decrease as moisture contents increased beyond the maximums respective to each sorption.

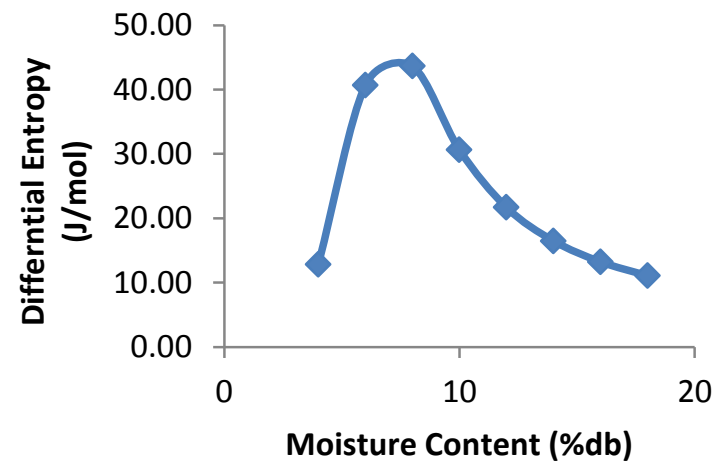

Figure 2. Variation of Entropy of Adsorption with Moisture Content

The $\Delta \mathrm{S}$ value is proportional to the number of active adsorption sides at the specified energy level (Tog rul \& Arslan, 2006). This means that the amount of available sorption sites decreases with increased moisture as the active site is covered by water molecules, thereby reducing their mobility (Aponte, 2016). According to some researchers 
(Eim, Rosello, Femenia, \& Simal, 2011; Goneli, Correa, Oliveira, \& Botelho, 2010), the decrease in differential entropy with increased moisture is associated with the restriction of the movement of water molecules.

Other researchers (Bonner \& Kenney, 2013) argue initial rise as moisture increases correspond closely to the monolayer moisture content calculated, indicating the sorption of water to accessible surface sites prior to the formation of a monolayer causes the material's surface to swell, allowing additional sorption sites to become available. After reaching the monolayer moisture content the entropy levels decrease exponentially as additional layers of moisture are formed and sorption sites become more limited and moisture accumulation approaches that of latent water (Iglesias \& Chirife, 1976)

The free energy changes of adsorption were calculated using Eq. (9) in the range of equilibrium moisture content of $2-18 \%$ dry basis. The free energy changes of adsorption for each given moisture content and temperature shown in Figure 3. The free energy changes of adsorption increase with the increase in moisture content.

All the free energy changes during adsorption are negative, confirming the strong attraction between the water molecule and the sample. This shows the strong hygroscopic nature of the sample. A negative trend towards the value of Gibbs-free energy is expected to emerge from the thermodynamic point of view because adsorption is a spontaneous process. Furthermore, Gibbs free energy is related to the work required to make the adsorption side available for sample swelling. The higher the moisture content, the lower the number of available sites so that the free energy falls. The rise in temperature promotes a reduction in the water content of the sample, which also explains the reduction of free energy as the temperature increases (Meze'e, Ngamveng, \& Bardet, 2008). Negative values for Gibbs free energy suggest strong intermolecular or connection interactions (related to enthalpy), which leads to a higher reduction of freedom in the configuration of water molecules, and consequently to a higher order in the system (related to entropy) (Rizvi, 2014).

The same trend of free energy found by earlier research. Previous research about bubinga, hardwood with a good natural resistance to fungi, termites, and wood borers, shows the same trend (Meze'e, Ngamveng, \& Bardet, 2008). Research about mango skin (Souza, Alves, Vieira, Vieira, Ramos, \& TelisRomero, 2015), and sugarcane bagasse (Teixeira, Andrade, \& Martins-Costa, 2015) show the same trend.

The spreading pressure was calculated using Eq. (11) in the range of water activity $0.1-0.9$. The spreading pressure as function of water activity was represented in Figure 4. The results show that the spreading pressure increases with increasing water activity. The same trend found by earlier research. Previous research about the oatmeal biscuit and oat flakes shows the same trend. In addition, the researcher suggesting that spreading pressure is affected by temperature. The higher the storage temperature the smaller the spreading pressure value (McMinn, McKee, \& Magee, 2007). Research about the walnut kernel (Togrul \& Arslan, 2007) starch powder (AlMuhtaseb, McMinn, \& Magee, 2004) show the same trend.

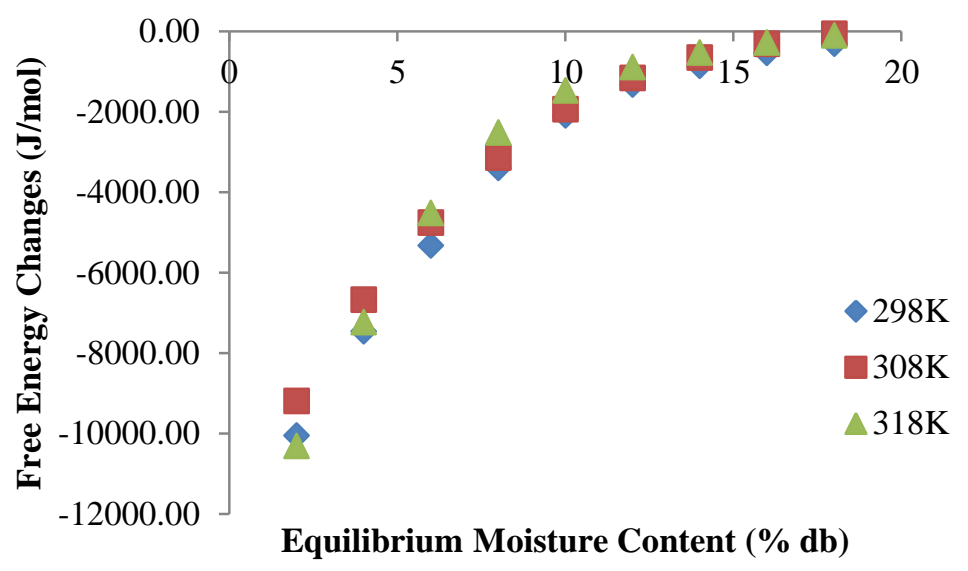

Figure 3. Variation of Free Energy Changes of Adsorption with Moisture Content 


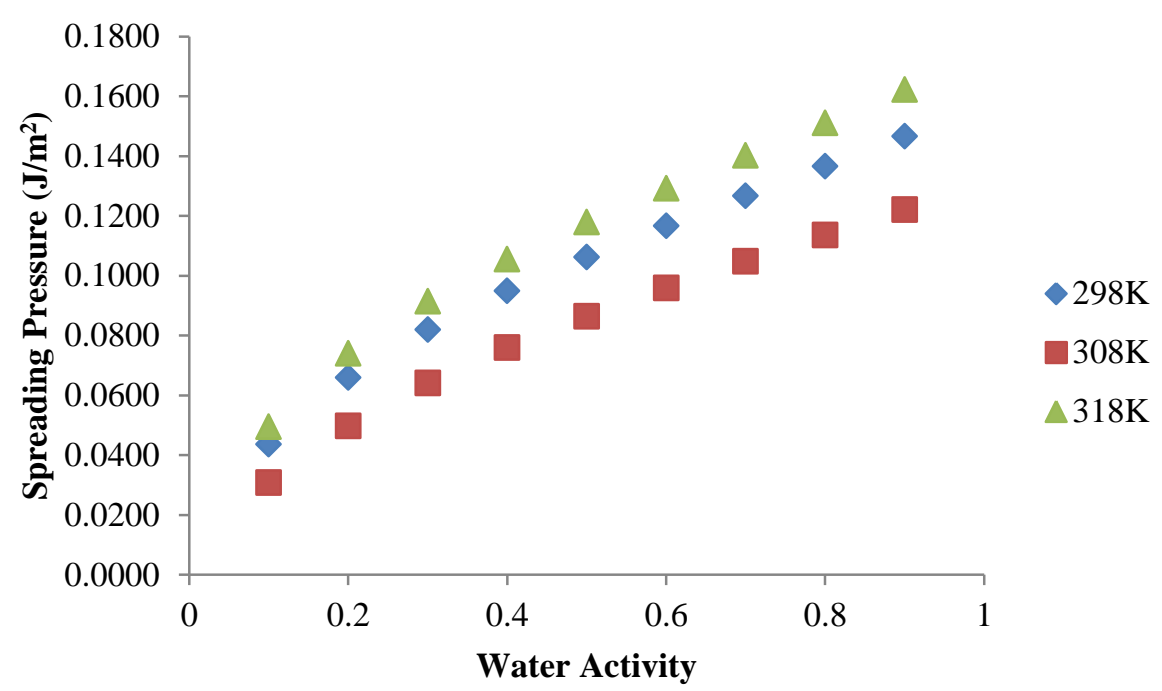

Figure 4. Spreading Pressure as Function of Water Activity

\section{CONCLUSIONS}

Isosteric heats of adsorption increases to maximum level and then decrease with increase in moisture content. Adsorption entropy increase to maximum level and then decrease with an increase in moisture content. The free energy changes increase with increase in moisture content. The spreading pressure increased with increasing water activity.

\section{ACKNOWLEDGEMENTS}

This research was supported by The Ministry of Research. Technology and Higher Education of Indonesia's Grant.

\section{REFERENCES}

Alfiah, M. N., Hartini, S., \& Cahyanti, M. N. (2017). Mathematical Models And Thermodynamic Properties Of Moisture Sorption Isotherms of Fermented Cassava Flour By Red Yeast Rice. Alchemy, 29-40.

Al-Muhtaseb, A., McMinn, W., \& Magee, T. (2004). Water Sorption Isotherm of Starch Powders. Part 2: Thermodynamic Characteristics. Journal of Food Engineering, 135-142.

Aponte, A. A. (2016). Thermodynamic Properties of Moisture Sorption in Cassava Flour. DYNA, 138-144.

Aviara, N., \& Ajibola, O. (2002). Thermodynamics of Moisture Sorption in Melon Seed and Cassava. Journal of Food Engineering, 107-113.
Basu, S., Shivhare, U., \& Mujumdar, A. (2006). Model for Sorption Isotherm for Foods: A Review. Drying Technology, 917-930.

Bonner, I. J., \& Kenney, K. L. (2013). Moisture sorption characteristics and modeling of energy sorghum (Sorghum bicolor (L.) Moench). Journal of Stored Products Research, 128-136.

Budijanto, S., Sitanggang, A., \& Kartika, Y. (2010). Penentuan Umur Simpan Tortilla dengan Metode Akselerasi Berdasarkan Kadar Air Kritis serta Pemodelan Ketepatan Sorpsi Isothermnya. 21(2).

Cahyanti, M. N., \& Pattiserlihun, A. (2017). Isoterm Sorpsi Air dari Tepung Komposit Gaplek and Biji Saga Pohon. Seminar Nasional Kimia dan Pendidikan Kimia IX. Solo: Universitas Negeri Sebelas Maret.

de Oliveira, G., Correa, P., de Oliveira, A., Reis, R., \& Devilla, I. (2015). Application of Gab Model for Water Desorption Isotherms and Thermodynamic Analysis of Sugar Beet Seeds. Journal of Food Process Engineering, 1-8.

Eim, V., Rosello, C., Femenia, A., \& Simal, S. (2011). Moisture Sorption Isotherms and Thermodynamic Properties of Carrot. International Journal of Food Engineering, 1-14.

Goneli, A., Correa, P., Oliveira, G., \& Botelho, F. (2010). Water Desorption and Thermodynamic Properties of Okra 
Seeds. American Society of Agricultural and Biological Engineers, 191-197.

Goula, A., Karapantsios, T., Achlilias, D., \& Adamopoulos, K. (2008). Water sorption isotherms and glass transition temperature of spray dried tomato pulp. Journal of Food Engineering, 73-83.

Iglesias, H., \& Chirife, J. (1976). Isosteric Heats of Water Vapor Sorption on Dehydrated Foods. Part I. Analysis of The Differential Heat Curves. Lebensmittel-Wissenschaft und Technology, 116-112.

Jha, E., Dahiya, V., \& Singh, A. (2014). Moisture Sorption Characteristics of Gluten Free Flour. International Journal of Agriculture and Food Science Technology, 27-34.

Maidawati, N. (2011). Pemanfaatan Tepun Biji Saga Pohon (Adenanthera pavonina Linn.) dalam Optimalisasi Pembuatan Tepung Gaplek Berprotein sebagai Bahan Substitusi Tepung Terigu. Salatiga: Universitas Kristen Satya Wacana.

Martinez-Navarrete, N., \& Chiralt, A. (1996). Influence of Roasting on The Water Sorption Isotherm of Nuts. Food Science and Technology International, 399-404.

McMinn, W., McKee, D., \& Magee, R. (2007). Moisture adsorption behaviour of oatmeal biscuit and oat flakes. Journal of Food Engineering, 481-493.

Meze'e, Y., Ngamveng, J., \& Bardet, S. (2008). Effect of enthalpy-entropy compensation during sorption of water vapour in tropical woods: The case of Bubinga (Guibourtia Tessmanii J. L'eonard; G. Pellegriniana J.L.). Thermochimica Acta, 1-5.

Monteagudo, I., \& Fierro, F. (2012). Moisture Sorption Isotherm and Thermodynamic Properties of Mexican Mennotite-Style Cheese. Journal of Food Science and Technology, 2393-2403.

Naveen, K., \& Das, S. (2015). Moisture Sorption Isotherm of Preconditioned Pressure Parboiled Brown Rice. Journal of Food Processing and Technology, 519-527.

Nayak, L., \& Pandey, J. (2000). Free energy change and monolayer moisture content of paddy and milled ride. Journal of the Institution of Engineers, 43-45.
Rizvi, S. S. (2014). Thermodynamic Properties of Foods in Dehydration. In M. A. Rao, S. S. Rizvi, A. K. Datta, \& J. Ahmed, Engineering Properties of Foods (p. 359). Boca Raton: CRC Press.

Rukmawati, Y., Hartini, S., \& Cahyanti, M. (2017). Isoterm Sorpsi Air pada Tepung Ubi Jalar Terfermentasi dengan Angkak. Jurnal Kimia Valensi, 71-78.

Sawhney, I. K., Sarkar, B., Pathil, G. R., \& Harish, K. S. (2013). Moisture Sorption Isotherms and Thermodynamic Properties of Whey Protein Concentrate Powder from Buffalo Skim Milk. Jounal of Food Processing and Preservation, 1787-1798.

Solomon, W., \& Zewdu, A. (2016). Thermodynamic properties of moisture adsorption in tef (eragrostis tef) seed. Engineering in Agriculture, Environment and Food, 1-7.

Sormoli, M., \& Langrish, T. (2014). Moisture Sorption Isotherms and Net Isosteric Heat of Sorption for Spray-Dryed Pure Orange Juice Powder. Food Science and Technology, 1-8.

Souza, S., Alves, A., Vieira, E., Vieira, J., Ramos, A., \& Telis-Romero, J. (2015). Study of thermodynamic water properties and moisture sorption hysteresis of mango skin. food science and technology, 157-166.

Taitano, L., Singh, R., Lee, J., \& Kong, F. (2012). Thermodynamic Analysis of Moisture Adsorption Isotherms of Raw and Blanched Almonds. Journal of Food Process Engineering, 840-850.

Teixeira, L., Andrade, E., \& Martins-Costa, M. (2015). Entropy and Gibbs Free Energy of Sugar Cane Bagasse. 23rd ABCM International Congress of Mechanical Engineering. Rio de Janeiro.

Telis, V., Gabas, A., Meneggalli, F., \& TelisRomero, J. (2000). Water sorption thermodynamic properties applied to persimmon skin and pulp. Thermochimica Acta, 49-56.

Tog rul, H., \& Arslan, N. (2006). Moisture Sorption Behaviour and Thermodynamic Characteristics of Rice Stored in a Chamber under Controlled Humidity. Biosystems Engineering, 181-195.

Togrul, H., \& Arslan, N. (2007). Moisture sorption isotherms and thermodynamic 
properties of walnut kernels. Journal of Stored Products Research, 252-264.

Yogendrarajah, P., Samapundo, S., Devlieghere, F., De Saeger, S., \& De Meulenaer, B. (2015). Moisture sorption isotherms and thermodynamic properties of whole black peppercorns (Piper nigrum L.). LWT - Food Science and Technology, 177-188. 